\title{
Analisis Mengenai Dampak Lingkungan Jalan Tol sebagai Bagian dari Manajemen Aset Infrastruktur \& Fasilitas
}

\author{
Environmental Impact Assessment of Toll Roads as Part of \\ Infrastructure Asset Management
}

\author{
Mohammad Razif ${ }^{1, a)}$ \\ 1) Jurusan Teknik Lingkungan, Institut Teknologi Adhi Tama, Surabaya \\ Koresponden : ${ }^{a)}$ mohammadrazif70@gmail.com
}

\begin{abstract}
ABSTRAK
Jalan tol termasuk infrasruktur beserta fasilitas yang memerlukan manajemen sebagai aset Negara yang dikelola oleh Operator Jalan Tol. Salah satu kewajiban manajemen jalan tol adalah menyusun dokumen amdal (Analisis Mengenai Dampak Lingkungan) yang diatur dalam PermenLH No 5/2012 untuk memperoleh izin lingkungan. Metoda amdal untuk rencana jalan tol mengacu ke PermenLH 16/2012, sedangkan metoda amdal untuk jalan tol yang sudah beroperasi mengacu ke PermenLHK P.102/2016. Untuk jalan tol yang masih dalam perencanaan, dampak yang harus dikelola dan dipantau yang dicantumkan dalam dokumen RKL (Rencana Pengelolaan Lingkungan) dan RPL (Rencana Pemantauan Lingkungan) relatif banyak karena dampak belum terjadi dan perlu dilakukan prinsip kehati-hatian untuk mengantisipasi segala kemungkian terjadinya dampak lingkungan yang bersifat negative dan meruaikan bagi masyarakat dan komponen lingkungan lainnya, pada seluruh tahap kegiatan (prakonstruksi, konstruksi, operasi). Untuk jalan tol yang sudah beroperasi, dampak yang harus dikelola dan dipantau yang dicantumkan dalam dokumen RKL-RPL relatif sedikit karena hanya dampak pada tahap operasi saja, dan besar dan pentingnya dampak bisa diukur karena sedang terjadi dan masih akan terjadi.
\end{abstract}

Kata Kunci : manajemen aset infrastruktur, jalan tol, amdal, RKL, RPL

\section{PENDAHULUAN}

Jalan tol termasuk infrasruktur beserta fasilitas yang memerlukan pengelolaan yang baik sebagai aset Negara yang dioperasikan oleh Operator Jalan Tol dalam bentuk Konsensi Operasional. Infrastruktur harus dikelola dengan baik agar tetap bisa berfungsi dengan baik, secara ekonomi, efisien, efektif dan selaras dengan prinsip "green" (Suprayitno \& Soemitro 2018). Oleh karena itu, salah satu kewajiban manajemen jalan tol adalah menyusun dokumen amdal (Analisis Mengenai Dampak Lingkungan) untuk memperoleh izin lingkungan, baik untuk jalan tol yang masih dalam taraf perencanaan, maupun jalan tol yang sudah lama beroperasi tapi masih belum mempunyai dokumen lingkungan. Kawajiban ini tertuang dalam PermenLH No 5/2012 (Anonim, 2012b). Untuk pedoman penyusunan dokumen amdal sendiri mengacu ke PermenLH 16/2012 (Anonim, 2012c), untuk jalan tol yang masih dalam perencanaanan dan untuk jalan tol yang sudah beroperasi lama mengacu ke PermenLHK No P.102/2016 (Anonim, 2016). Apabila jalan tol yang direncanakan atau yang sudah beroperasi tidak memiliki izin lingkungan maka manajemennya akan terkena sangsi pidana maksimum 3 tahun dan denda maksimum 3 miliar. Ketentuan ini berlaku tidak hanya untuk jalan tol saja, tapi juga untuk semua rencana usaha dan/atau kegiatan bidang PU, termasuk infrastruktur dan 
fasilitasnya seperti bandara, pelabuhan laut, jalan kereta api, bendungan, jembatan, sistim drainase, sistem penyediaan air bersih, reklamasi pulau dan pantai, tempat pengelolaan akhir sampah, incinerator sampah dan lain-lainnya yang semuanya ada dalam daftar di lampiran PermenLH 5/2012 (Anonim, 2012b). Penyusun dokumen amdal disyaratkan harus memenuhi kompetensi yang dikeluarkan oleh lembaga sertifikasi professional setelah melewati uji kompetensi. Minimal dalam setiap studi amdal harus didukung oleh 1 orang dengan sertifikat KTPA (Ketua Tim Penyusun Amdal) dan 2 orang dengan sertifikat ATPA (Anggota Tim Penyusun Amdal). Baik sertifikat KTPA maupun sertifikat ATPA berlaku hanya selama 3 tahun dan harus diperbarui kembali. Penyusun amdal yang tidak mempunyai sertifikat kompetensi juga diancam pidana maksimum 3 tahun dan denda maksimum 3 miliar. Pejabat yang menerbitkan izin lingkungan tanpa dokumen amdal atau UKL-UPL juga terancam pidana maksimum 3 tahun dan denda maksimum 3 miliar. Ketentuan pidana dan denda ini diatur dalam UU 32/2009 tentang Perlindungan dan Pengelolaan Lingkungan Hidup. Morrison. \& Bailey. (2008) menulis bahwa praktisi di Australia Barat telah memperoleh manfaat dari kursus pelatihan amdal, seminar dan acara lainnya dilaksanakan di bawah naungan perjanjian kemitraan yang memberikan kesempatan bagi regulator dan konsultan untuk bercampur dan bersosialisasi bersama-sama. Praktisi tertarik untuk lebih mengembangkan interaksi kolaboratif, misalnya, lokakarya terstruktur atau pertemuan meja bundar yang bertujuan untuk berbagi pelajaran dan cara bekerja untuk meningkatkan praktek amdal. Berdasarkan pengalaman-pengalaman positif di Australia Barat disarankan agar praktisi amdal di wilayah lain di seluruh dunia dapat mengambil manfaat dari jenis pendekatan kooperatif ini untuk meningkatkan praktek AMDAL. Di Indonesia KLH telah mensponsori kolaborasi antara stakeholder Amdal dengan melakukan pertemuan rutin setiap bulan untuk saling berbagi pelajaran dan informasi.

Runhaar $\mathrm{H}$ et al (2012) menulis bahwa berdasarkan desain penelitian yang inovatif yang terdiri dari survei online dengan 443 responden dan 20 tambahan wawancara semi-terstruktur di Belanda disimpulkan bahwa wacana dominan tentang penilaian lingkungan adalah terutama terkait persyaratan hukum, penilaian lingkungan dilakukan karena harus dilakukan, bukan karena pelaku memilih untuk melakukannya. Sedangkan Panigrahi J.K \& Amirapu S. (2012) menulis bahwa Pemerintah India menunjukkan tingkat komitmen yang tinggi. Sistem amdal di negara ini sedang mengalami perbaikan progresif dengan terus berupaya menghapus berbagai kendala. Penulis ini mengidentifikasi peluang untuk mengambil keuntungan dari situasi saat itu untuk memperkuat proses amdal. Alshuwaikhat (2005) menulis bahwa upaya terkoordinasi antara semua pihak pemerintah, nonpemerintah, dan organisasi internasional yang terlibat dengan kebijakan, rencana dan program yang memungkinkan negara-negara berkembang untuk menjalani pembangunan berkelanjutan melalui pengembangan dan penerapan kajian lingkungan hidup strategis. Jay S. et al (2007) menulis bahwa efektivitas amdal akan didukung jika tujuan khususnya adalah untuk memberikan lingkungan bersih dan, jika hal ini tidak dapat dibuktikan, diminta untuk menerapkan prinsip kehati-hatian dalam pengambilan keputusan. Tidak ada keraguan bahwa, jika masyarakat dan politisi sudah berhasil, Amdal dapat menyediakan sarana yang jauh lebih efektif untuk terlibat dengan proses perencanaan dan untuk mencapai pola pembangunan yang lebih berkelanjutan. Sedangkan Pischke F. \& Cashmor M. (2006) menulis bahwa analisis menunjukkan bahwa ada alasan yang jauh lebih umum di banyak perdebatan kontemporer tentang penilaian lingkungan dari literatur, yang cenderung menunjukan polarisasi, dimana penelitian ini mengakui dan menyoroti adanya kontribusi teori yang berorientasi keputusan untuk memfokuskan kembali perhatian kepada maksud substantif memakai alat kebijakan yang signifikan ini secara global.

Penelitian ditujukan untuk mengevaluasi dampak lingkungan penting yang harus dikelola dan dipantau dalam dokumen RKL dan RPL dari kegiatan jalan tol, baik untuk 
kegiatan jalan tol yang masih dalam perencanaan, maupun kegiatan jalan tol yang sudah beroperasi.

\section{STUDI PUSTAKA}

Menurut PermenLH 5/2012 (Anonim, 2012b) jenis kegiatan jalan tol yang masuk kategori wajib amdal adalah sebagai berikut.

a. Untuk Kota Metropolitan/besar: jika panjang jalan $=5 \mathrm{~km}$ atau pengadaan lahan luasnya $>10$ ha

b. Untuk Kota Sedang : jika panjang jalan $=5 \mathrm{~km}$ atau pengadaan lahan luasnya $>20$ ha

c. Untuk pedesaan : jika panjang jalan $=5 \mathrm{~km}$ atau pengadaan lahan luasnya $>30$ ha Alasan ilmiah perlunya studi amdal untuk jalan tol disebutkan antara lain :

a. Bangkitan lalu lintas, dampak kebisingan getaran, emisi yang tinggi, gangguan visual dampak dampak sosial

b. Alih fungsi lahan.

Menurut PermenLH 16/2012 (Anonim, 2012c), dokumen amdal yang perlu disusun mencakup: Kerangka Acuan, ANDAL dan RKL dan RPL. Kerangka Acuan harus memuat: pendahuluan, pelingkupan, metode studi, daftar pustaka dan lampiran. ANDAL harus memuat: pendahuluan, deskripsi rinci rona lingkungan hidup awal, prakiraan dampak penting, evaluasi secara holistik terhadap lingkungan, daftar pustaka dan lampiran. RKL dan RPL harus memuat: pendahuluan, rencana pengelolaan lingkungan hidup, rencana pemantauan lingkungan hidup, jumlah dan jenis izin perlindungan dan pengelolaan lingkungan hidup yang dibutuhkan, pernyataan komitmen pemrakarsa untuk melaksanaakan ketentuan yang tercantum dalam RKL dan RPL, daftar pustaka, dan lampiran.

Menurut PermenLHK P.102/2016 (Anonim, 2016), dokumen evaluasi lingkungan hidup (DELH) harus memuat: pendahuluan, usaha dan/atau kegiatan yang telah berjalan, evaluasi dampak, rencana pengelolaan dan pemantauan lingkungan hidup, jumlah dan jenis izin perlindungan dan pengelolaan lingkungan hidup, pernyataan komitmen penanggung jawab usaha dan/atau kegiatan untuk melaksanakan ketentuan yang tercantum dalam DELH, daftar pustaka, dan lampiran. Penyusun DELH harus memenuhi persyaratan: memiliki sertifikat kompetensi auditor lingkungan hidup, memiliki sertifikat kompetensi penyusun dokumen amdal, memiliki sertifikat kelulusan pelatihan penyusun amdal dan/atau memiliki sertifikat kelulusan pelatihan auditor lingkungan hidup.

Dalam penyusunan amdal perlu melibatkan masyarakat dan kegiatan pelibatan masyarakat dapat dilakukan melalui pengumuman dan konsultasi publik. Prosedur pelibatan masyarakat dalam proses Amdal harus mengacu pada peraturan perundangundangan seperti PP 27/2012 (Anonim, 2012a) dan PermenLH 17/2012 (Anonim, 2012d). Tidak semua proses partisipasi masyarakat dalam amdal berjalan sempurna, Toro J. et.al (2009) menulis bahwa di Kolombia, partisipasi masyarakat dalam proses amdal sangat diskriminatif karena konsultasi dan partisipasi masyarakat yang terjadi adalah hanya untuk populasi hitam atau penduduk asli, jika proyek itu memang secara langsung mempengaruhi wilayah di mana mereka tinggal. Sisa penduduk lainnya, partisipasinya berkurang sehingga tidak memperoleh informasi yang lengkap tentang rencana proyek. Di Indonesia proses partisipasi masyarakat dalam amdal juga belum berjalan sempurna. Sesuai dengan ketentuan dalam PermenLH 17/2012 (Anonim, 2012d) tidak semua masyarakat terkena dampak dilibatkan dalam sosialisasi dan konsultasi publik, pelibatannya melewati mekanisme perwakilan. Dalam sidang komisipun masyarakat yang terkena dampak hadir lewat mekanisme perwakilan (masyarakat menunjuk wakil yang akan mengikuti sidang komisi amdal). O'Faircheallaigh C (2009) berargumen bahwa model partisipasi masyarakat perlu juga memperhatikan bahwa untuk interaksi yang terjadi dapat dalam bentuk yang berbedabeda, dan fakta bahwa partisipasi masyarakat menimbulkan isu mengenai kendali atas 
pengambilan keputusan yang umumnya tidak tunduk pada resolusi, tetapi harus dikelola melalui proses perundingan (negosiasi). Di Indonesia prosesnya hampir sama, umumnya masyarakat yang terkena dampak menunjuk wakil-wakil meraka dalam tim yang akan bernegosiasi dengan pihak pemrakarsa untuk proses kompensasi, pemanfaatan tenaga kerja lokal, program-program CSR (corporate social responsibility) dan sebagainya.

Nadeem O \& Hameed R. (2008) menulis bahwa di Pakistan pengaruh amdal terhadap pembuatan keputusan adalah lemah, karena berbagai alasan yang berkaitan dengan sumber daya yang tidak memadai dari aspek teknis dan keuangan, kekurangan dalam penyaringan dan penentuan cakupan (penapisan dan pelingkupan), lemahnya koordinasi, review yang bersifat subyektif, partisipasi publik yang tidak efektif dan tidak adanya pemantauan resmi. Hourdequin M. et al (2011) menulis tentang partisipasi masyarakat dalam amdal di Amerika Serikat dan menyebutkan bahwa peningkatan partisipasi dalam proses amdal partisipatif tidak menjamin hasil yang lebih baik dalam pengelolaan lingkungan. Namun empat prinsip etika berasal dari teori demokrasi dapat menyebabkan peningkatan keterlibatan publik dan kepuasan dengan keputusan instansi pemerintah, yaitu : adanya kesempatan yang sama untuk berpartisipasi, akses yang sama terhadap informasi, adanya musyawarah, dan adanya komitmen bersama. Kondisi ini hampir sama dengan di Indonesia. Partisipasi masyarakat lebih banyak terkait dengan identifikasi dampak penting untuk pelingkupan. Sedangkan ketajaman pengelolaan lingkungan dalam dokumen RKL sangat tergantung pada ketajaman dari tim teknis dalam menanggapi hasil penyusunan RKL oleh penyusun amdal. Jika tim teknis dilengkapi dengan pakar yang sesuai maka dokumen pengelolan lingkungan (RKL) makin lengkap dan rinci sehingga ada peluang besar untuk hasil yang lebih baik dalam implementasi pengelolaan lingkungan (biasanya pemrakarsa menandatangani surat kesanggupan melaksanakan RKL dan RPL diatas meterai).

Hartley \& Wood (2005) menyimpulkan bahwa Konvensi Aarhus yang diterapkan di Inggris mengarah pada penguatan prosedur partisipasi dan peningkatan akan sangat tergantung pada bagaimana memasukkan ke dalam undang-undang dan praktek. Di Indonesia ketentuan tentang partisipasi masyarakat dalam amdal dan izin lingkungan sudah diatur cukup rinci dalam PermenLH 17/2012 (Anonim, 2012d). Armitage (2005) juga menulis tentang kolaborasi penilaian lingkungan di Kanada dan menyoroti isu-isu kunci untuk meningkatkan kolaborasi dalam praktek meliputi: (1) pengembangan peraturan organisasi terdesentralisasi yang lebih responsif terhadap perubahan keadaan (2) strategi untuk komunikasi yang lebih efektif dan partisipasi untuk kepentingan masyarakat (3) upaya untuk membangun visi kolaboratif pembangunan ekonomi dan sosial melalui kawasan khusus dari rencana penggunaan lahan (4) integrasi kerangka pengetahuan dan (5) perhatian dengan kapasitas yang dibutuhkan untuk mendorong intervensi yang efektif dalam proses penilaian. Di Indonesia praktek kolaborasi antara stakeholder amdal umumnya sudah berjalan cukup baik (ada pertemuan rutin setiap bulan yang diprakarsai oleh KLH).

Penelitian di Afrika Selatan yang dilakukan oleh Sandham L.A \& Pretorius H.M (2007) memberikan hasil bahwa $86 \%$ dari laporan yang diteliti hasilnya berada pada nilai yang memuaskan. Penulis yang sama Sandham L.A et al (2011) meneliti lebih lanjut dan menghasilkan bahwa meskipun beberapa perbaikan dalam aspek-aspek tertentu, kualitas laporan keseluruhan mengalami sedikit penurunan dari tahun 1997 pada saat periode puncak Amdal. Oleh karena itu modifikasi peraturan, yang sering digembar-gemborkan sebagai solusi untuk perbaikan kinerja belum menghasilkan peningkatan kualitas laporan amdal di Afrika Selatan. Di Indonesia telah dilakukan penelitian kualitas dokumen amdal yang dilakukan oleh KLH (dipublikasikan terbatas di pelatihan amdal) untuk dokumen yang telah disetujui antara tahun 2001 sampai 2004 yang mayoritas berasal dari propinsi dan kabupaten/kota, dimana hasil penilaiannya adalah $63 \%$ dokumen bernilai dibawah 50 (buruk). Oleh sebab itu 
kemudian dilakukan perbaikan regulasi dengan UU 32/2009 (Anonim, 2009), PP27/2012 (Anonim, 2012a), dan berbagai PermenLH.

Branis \& Christopoulos (2005) menulis bahwa meskipun ada latar belakang hukum yang baik untuk mengumpulkan data monitoring di tahap pelaksanaan dan operasi tahap dari pengembang baru, peraturan amdal di Ceko tidak memberikan latar belakang dukungan yang praktis untuk kegiatan ini. Tanpa dukungan kelembagaan, pribadi dan keuangan yang relevan kemungkinan untuk memaksakan pemantauan pasca proyek untuk pengembang tetap sebuah tantangan, dan bukan keuntungan dari peraturan amdal di Ceko. Annandale \& Taplin (2003) menulis bahwa sebagian besar perusahaan melihat AMDAL sebagai katalis untuk mengintegrasikan desain lingkungan ke dalam perencanaan awal proyek, sehingga mengurangi kebutuhan untuk menghabiskan uang untuk mengatasi masalah lingkungan sekali proyek yang dirancang buruk dimplementasikan. Yang agak mengejutkan kesimpulan bahwa perusahaan melihat regulasi persetujuan lingkungan sama pentingnya, tapi sebagai dorongan untuk pembangunan dan bukan sebagai hambatan, bertentangan dengan banyak industri sebelumnya dan komentar akademik dan, setidaknya dalam kaitannya dengan sektor pertambangan, membantah ide bahwa amdal itu berat.

\section{METODA PENELITIAN}

Uraian metoda penelitian ini dibagai dalam dua golongan metoda yaitu : metoda untuk menganalisa sebuah rencana jalan tol dan metoda untuk menganalisa jalan tol yang sudah beroperasi. Kedua metoda disampaikan sebagai berikut.

a. Metoda Amdal untuk rencana jalan tol yang mengacu ke PermenLH 16/2012 (Anonim, 2012c), yang secara garis besar besar mencakup:

- Metode Pelingkupan untuk penentuan Jenis dampak yang dikaji, batas wailayah studi dan batas waktu kajian

- Metoda Pengumpulan dan Analisis data dari Rona Lingkungan

- Metoda Prakiraan Pentingnya dampak memakai metoda formal dan non formal untuk prakiraan besarnya dampak, dan pemakaian 7 kriteria untuk penetuan sifat pentingnya dampak

- Metoda Evaluasi Holistik menggunakan matrik dan bagan alir (Fandeli, 2000).

- Metoda RKL dan RPL menggunakan matrik

Metode diatas tidak berbeda jauh dengan metode yang telah ditulis oleh Anjaneyulu \& Manickam (2011), dan oleh Mariott (1997) terkait proses pelingkupan.

b. Metoda Amdal untuk jalan tol yang sudah beroperasi mengacu ke PermenLHK P.102/2016 (Anonim, 2016), yang secara garis besar mencakup:

- Metoda pengumpulan dan analisis data kegiatan yang sudah berlangsung

- Metoda evaluasi dampak memakai metoda audit lingkungan

- Metoda RKL dan RPL menggunakan matrik

Data yang dikumpulkan dalam penulisan jurnal ini mengacu pada hasil studi Amdal yang sudah disusun oleh penulis dan kawan-kawan, untuk Amdal jalan tol yang sedang direncanakan (Mursid et al, 2015a) dan Amdal jalan tol yang sudah beroperasi (Mursid et al, 2015b).

Momtaz S. (2002) menulis bahwa di Bangladesh pelingkupan adalah fase penting dalam melakukan studi amdal. Ini adalah tahap ketika wilayah geografis dan isu-isu yang harus dipertimbangkan dalam studi amdal ditentukan. Pada tahap awal aplikasi amdal di Bangladesh, tahap pelingkupan ini tidak jelas bagi individu dan kelompok yang terlibat dalam pelaksanaan amdal. Pemahamannya adalah bahwa semua komponen / sektor yang diperiksa dalam proyek-proyek besar juga harus dipertimbangkan dalam proyek-proyek kecil. Namun, kemudian, baru jelas bahwa hanya komponen yang relevan dengan proyek yang harus 
dipertimbangkan dalam tahap pelingkupan. Misalnya, jika kesehatan masyarakat bukan masalah untuk proyek pembangunan jalan, maka tidak perlu membuang untuk melingkup masalah itu. Opoku (2001) menulis bahwa para pembuat kebijakan di negara berkembang, termasuk Ghana, harus belajar bahwa pengetahuan adat bukan hanya peninggalan dari masa lalu, tetapi adalah sesuatu yang penting sekarang dan akan bernilai di masa depan. Untuk mencapai hal ini, pendidikan harus diarahkan untuk transmisi dari satu generasi ke generasi berikutnya dari akumulasi kebijaksanaan dan pengetahuan masyarakat, dan penyiapan orang muda untuk partisipasi efektif dalam pemeliharaan dan pengembangan masyarakat. Dalam pengertian ini, amdal bisa menjadi bagian dari solusi untuk mencegah hilangnya pengetahuan adat dengan meningkatkan partisipasi masyarakat adat dalam studi amdal.

\section{ANALISIS DAN PEMBAHASAN}

\section{Amdal Jalan Tol yang Direncanakan}

Berdasarkan hasil pelingkupan diperoleh dampak penting hipotetik (DPH) sebagai berikut: Tahap Prakonstruksi: peningkatan keresahan masyarakat, penurunan produksi pertanian, dan penurunan produksi tambak. Tahap Konstruksi: penurunan kualitas air permukaan, penurunan kualitas air tanah, peningkatan timbulan sampah, penurunan sanitasi lingkungan, gannguan fungsi gorong-gorong dan drainase eksisting, penurunan kualitas udara, penurunan flora darat, berkurangnya lahan pertanian, peningkatan timbulan sampah, peningkatan kesempatan kerja, peningkatan peluang berusaha, mata pencaharian masyarakat, peningkatan kecemburuan sosial, peningkatan kebisingan, peningkatan getaran, peningkatan kerusakan jalan, berkurangnya kenyamanan lalu lintas, peningkatan kemacetan lalu lintas, berkurangnya RTH sebagai daerah resapan, peningkatan limpasan air permukaan, banjir (genangan air sekitar lokasi), penurunan aksesbilitas masyarakat, berkurangnya biota perairan, peningkatan flora darat, peningkatan fauna darat. Tahap operasi: peningkatan PAD, peningkatan kebisingan, penurunan kualitas udara, penurunan aksesibilitas masyarakat. Hasil evaluasi holistic diperlihatkan di Tabel 1 (Mursid et al, 2015b). Untuk dampak yang dikelola dan dipantau telah dibuatkan matrik RKL dan RPL sebagai pedoman bagi pelaksana, pengawas dan penerima laporan.

Tabel 1. Hasil Evaluasi Holistik Rencana Jalan Tol

\begin{tabular}{clc}
\hline No & Keterangan & Jumlah \\
\hline 1 & Dampak Penting Hipotetik Hasil Pelingkupan & 85 \\
2 & Hasil Prakiraan Besaran Dampak (Skala 3,4,5) & 43 \\
3 & Hasil Prakiraan Sifat Penting Dampak (Skala 3,4,5) & 43 \\
4 & Dampak Dikelola dan Dipantau (besar dan penting) & 43 \\
5 & Dampak Dipantau saja (dampak positif yang & 6 \\
& dipertahankan) & 42 \\
6 & Dampak Tidak Dikelola dan Tidak Dipantau (Skala 1,2) & 42 \\
\hline
\end{tabular}

Terkait dengan dampak penurunan kulitas udara ini telah dilakukan prediksi dari $\mathrm{CO}$, CO2, CH4 dan N2O dari emisi kendaraan tahun 2014-2048, yang menghasilkan persamaan regresi yang bisa dipakai untuk menghitung besarnya emisi setiap tahunnya (Razif \& Santoso, 2016).

Menurut PermenLH 16/2012 Rencana Pengelolaan Lingkungan (RKL) adalah upaya penanganan dampak lingkungan yang ditimbulkan dari rencana usaha dan/atau kegiatan. Upaya penanganan dampak lingkungan mencakup spektrum prosedur yang sangat luas, dan beberapa contoh diantaranya adalah sebagai berikut :

1. Jarvis \& Younger (2000) beranggapan bahwa melibatkan masyarakat lokal dalam kegiatan remediasi akan memberi banyak manfaat. Di Indonesia banyak kegiatan 
pertambangan yang setelah selesai sering mengabaikan kegiatan remediasi yang seharusnya melibatkan masyarakat sekitar. Akibatnya masyarakat sekitar tidak dapat memanfaatkan lahan-lahan bekas pertambangan, sehingga mereka hanya terkena dampak yag tidak dikelola dengan baik.

2. Saarikoski (2000) beranggapan bahwa proses kerjasama dalam Amdal (penanganan dampak) seharusnya melibatkan mediator untuk melindungi kebebasan peserta untuk mengungkapkan pendapat untuk kesepakatan bersama. Di Indonesia proses pemanfaatan mediator umumnya masih lemah. Aparat pemerintah seringkali tidak ingin ikut campur jika terjadi permasalahan antara masyarakat dengan pemrakarsa yang diakibatkan oleh dampak lingkungan. Banyak aparat yang yang lebih menganjurkan penyelesaian lewat pengadilan dibanding dengan lewat kerjasama. Contoh-contoh nya ada pada perusahaan-perusahaan besar yang beroperasi di Papua, Sulawesi, Kalimantan, dan Sumatra.

3. Turnbull (2002) menulis bahwa di Fiji, pengelolaan lingkungan sangat terkait dengan aspek sosial, politik dan ekonomi. Di Indonesia di jumpai hal yang sama, karena banyak sekali aspek sosial, politik dan ekonomi yang mengakibatkan tidak berjalannya kegiatan pengelolaan lingkungan yang optimal. Sebuah pabrik gula milik BUMN di Jawa Timur yang di tutup oleh Gubernur Jawa Timur karena limbahnya mencemari Kali Surabaya, akhirnya dibuka kembali karena pertimbangan masalah sosial (petani tebu yang tidak terserap produknya), masalah politik (demo dari pekerja yang terancam penghasilannya) dan masalah ekonomi (kerugian perusahaan karena tidak beroperasi).

\section{Amdal Jalan Tol yang Sudah Beroperasi}

Hasil evaluasi dampak menggunakan metoda audit lingkungan telah memperoleh hasil yang diperlihatkan di Tabel 2 (Mursid, et al, 2015a).

Tabel 2. Hasil Evaluasi Dampak Jalan Tol yang sudah beroperasi

\begin{tabular}{|c|c|c|c|}
\hline No & Dampak Lingkungan & $\begin{array}{l}\text { Hasil Evaluasi Skala } \\
\text { Besar Dampak }\end{array}$ & $\begin{array}{l}\text { Hasil Evaluasi Skala } \\
\text { Penting Dampak }\end{array}$ \\
\hline 1 & $\begin{array}{l}\text { Peningkatan aksesibilitas bagi masyarakat } \\
\text { pengguan jalan tol dari kegiatan pengoperasian } \\
\text { gerbang tol }\end{array}$ & 4 = dampak besar & 4 = dampak penting \\
\hline 2 & $\begin{array}{l}\text { Peningkatan paparan emisi pada petugas dari } \\
\text { kegaiatan pengoperasian gerbang tol }\end{array}$ & $3=$ dampak sedang & $4=$ dampak penting \\
\hline 3 & $\begin{array}{l}\text { Timbulnya limbah padat dari kegiatan ceceran } \\
\text { material saat terjadi kecelakaan }\end{array}$ & $3=$ dampak sedang & $4=$ dampak penting \\
\hline 4 & $\begin{array}{l}\text { Peningkatan limbah toilet dari kegiatan } \\
\text { pengoperasian kantor }\end{array}$ & $2=$ dampak kecil & $\begin{array}{c}2=\underset{\text { dampak tidak }}{\text { penting }} \\
\text { penting }\end{array}$ \\
\hline 5 & $\begin{array}{l}\text { Peningkatan timbulan sampah kantor dari } \\
\text { kegaiatan pengoperasian kantor }\end{array}$ & $2=$ dampak kecil & $\begin{array}{c}2=\text { dampak tidak } \\
\text { penting }\end{array}$ \\
\hline 6 & $\begin{array}{l}\text { Peningkatan kesempatan kerja dari kegiatan } \\
\text { pengoperasian kantor }\end{array}$ & $2=$ dampak kecil & $\begin{array}{c}2=\text { dampak tidak } \\
\text { penting }\end{array}$ \\
\hline 7 & $\begin{array}{l}\text { Peningkatan timbulan limbah B3 dari kegiatan } \\
\text { pengoperasian jalan tol }\end{array}$ & $3=$ dampak sedang & $4=$ dampak penting \\
\hline 8 & $\begin{array}{l}\text { Penurunan kualitas udara dari kegiatan } \\
\text { pengoperasian jalan }\end{array}$ & $3=$ dampak sedang & $4=$ dampak penting \\
\hline 9 & $\begin{array}{l}\text { Peningkatan kebisingan dri kegiatan } \\
\text { pengoperasian jalan }\end{array}$ & $4=$ dampak besar & $4=$ dampak penting \\
\hline 10 & $\begin{array}{l}\text { Perubahan tingkat kemacetan dari kegiatan } \\
\text { pengoperasian jalan }\end{array}$ & $2=$ dampak kecil & $\begin{array}{l}3=\text { dampak cukup } \\
\text { penting }\end{array}$ \\
\hline 11 & Banjir dari kegiatan pengoperasian jalan tol & $4=$ dampak besar & $4=$ dampak penting \\
\hline 12 & $\begin{array}{l}\text { Peningkatan disiplin pengguna jalan dari } \\
\text { kegaiatn pengoperasian patroli }\end{array}$ & $3=$ dampak sedang & $4=$ dampak penting \\
\hline 13 & $\begin{array}{l}\text { Peningkatan kecepatan pertolongan dari } \\
\text { kegiatan pengoperasian patroli/ambulan/derek }\end{array}$ & $4=$ dampak besar & $4=$ dampak penting \\
\hline
\end{tabular}


14

Penurunan pelanggaran lalu lintas dari kegaiatan pengoperasian patrol/ambulan/derek

15 Gangguan aktivitas petani garam dari kegiatan pemagaran sisi jalan tol

16 Perubahan tingkat kecelakaan dari kegaiatan pemakai jalan yang tidak disiplin

17 Perubahan tingkat kemacetan dari kegaiatan pemakai jalan yang tidak disiplin

18 Perubahan tingkat kecelakaan dari kegiatan pemeliharaan jalan tol

$$
\begin{array}{ll}
4 \text { = dampak besar } & 4 \text { = dampak penting } \\
3 \text { = dampak sedang } & 4 \text { = dampak penting } \\
4 \text { = dampak besar } & 4=\text { dampak penting } \\
2 \text { = dampak kecil } & 4=\text { dampak penting } \\
4 \text { = dampak besar } & 4=\text { dampak penting }
\end{array}
$$

Dari tabel diatas, dampak yang akan dikelola dan dipantau hanyalah hasil evaluasi yang menghasilkan dampak besar dan penting diatas skala 3, yaitu sebanyak 15 dampak, sedangkan untuk dampak no 4,5,6 meskipun tidak besar dan tidak penting tetapi sudah otomatis dikelola oleh perusahaan selama ini. Untuk dampak yang dikelola dan dipantau telah dibuatkan matrik RKL dan RPL sebagai pedoman bagi pelaksana, pengawas dan penerima laporan.

Terkait dengan dampak penurunan kulitas udara dari pengoperasian jalan telah dilakukan prediksi dari emisi kendaraan tahun 2011-2013, yang menghasilkan emisi sisi jalan Surabaya ke Gresik masing-masing sebesar $\mathrm{CH}_{4} 995 \mathrm{~g} / \mathrm{jam}, \mathrm{CO} 610902 \mathrm{~g} / \mathrm{jam}, \mathrm{N}_{2} \mathrm{O} 202 \mathrm{~g} / \mathrm{jam}$, $\mathrm{CO}_{2} 6108403 \mathrm{~g} / \mathrm{jam}$ dan emisi sisi jalan Gresik ke Surabaya CH4 2214 g/jam, CO 1358569 g/jam, $\mathrm{N}_{2} \mathrm{O} 449$ g/jam, $\mathrm{CO}_{2} 13584314$ g/jam (Razif \& Persada, 2016).

Evaluasi dampak pembangunan dan pengoperasian jalan tol memang lebih mudah jika dibandingkan dengan evaluasi dampak pengoperasian jalan raya untuk rute truk sampah menuju TPA yang bisa dikaji optimasinya menghasilkan dengan maksimalisasi persinggahan (Suprayitno \& Soemitro, 2017). Dari aspek lingkungan implikasi rute jalan yang dilewati akan menimbulkan dampak yang berbeda, karean rona lingkungan setiap jalan tidak sama (Yakin, 1997). Secara umum akan timbul dampak fisik (rusaknya jalan), dampak transporatasi (kemacetan lalu lintas jika truk sampah beroperasi siang hari), dampak sosial (kurangnya kenyamanan dan keselamatan lalu lintas warga yang jalannya dilewati truk sampah), dampak kesehatan masyarakat (sebaran penyakit jika truk sampah yang dipakai tidak terjamin dari tumpahan dan ceceran sampah). Karena kegiatan pengangkutan sampah ini tidak masuk ruang lingkup amdal menurut PermenLH 5/2012, maka penyelesaian hanya bisa lewat Andal Lalin. Sayangnya tidak semua kota mempunyai Perda Andal Lalin. Meskipun Andal Lalin bisa dibebani untuk mengevaluasi dampak lingkungan pengangkutan sampah, masih jarang dilakukan optimasi (Soemitro \& Hitapriya, 2018) terkait dengan kapasitas truk pengangkut sampah yang sering membludak dan menimbulkan cecaran dan bau di jalan dan pemukiman warga yang dilewati oleh truk sampah.

Memang harus diakui bahwa tidak semua dokumen amdal mutunya bagus. Mutu yang kurang memuaskan juga diperoleh dari implementasi amdal di Estonia, dimana menurut Heinma K \& Poder T (2010) hasil yang diperoleh menunjukkan bahwa efektivitas sistem amdal saat itu tidak cukup. Tingginya proporsi tidak menyusun amdal tidak hanya pemborosan sumber daya tetapi juga menekan efektivitas sistem amdal secara keseluruhan. Ini juga memiliki pengaruh negatif tidak langsung terhadap kredibilitas amdal sebagai alat pengelolaan lingkungan di mata pihak yang terlibat. Di Indonesia pada tahun 2008 kondisi mutu dokumen amdal juga tidak sebagus saat ini, dimana peningkatan mutu dokumen amdal di Indonesia semangkin meningkat setelah diberlakukannya persyaratan kompetensi penyusun, persyaratan mutu LPK dan LSP, dan persyaratan Lisensi Komisi Penilai Amdal yang baru dimulai tahun 2010 sejak diberlakukannya UU 32/2009 (Anonim, 2009).

\section{KESIMPULAN}

Penelitian ini menghasilkan dua buah kesimpulan utama. Kedua kesimpulan utama tersebut disampaikan sebagai berikut. 
1. Untuk Jalan Tol yang masih dalam perencanaan, dampak yang harus dikelola dan dipantau yang dicantumkan dalam dokumen RKL-RPL relatif banyak karena dampak belum terjadi dan perlu dilakukan prinsip kehati-hatian untuk mengantisipasi segala kemungkian terjadinya dampak lingkungan yang bersifat negative dan merugikan bagi masyarakat dan komponen lingkungan lainnya, pada seluruh tahap kegiatan (Prakonstruksi, konstruksi, operasi)

2. Untuk Jalan Tol yang sudah beroperasi, dampak yang harus dikelola dan dipantau yang dicantumkan dalam dokumen RKL-RPL reltif sedikit karena hanya dampak pada tahap operasi saja, dan besar dan pentingnya dampak bisa diukur karena sedang terjadi dan masih akan terjadi.

\section{DAFTAR PUSTAKA}

Alshuwaikhat, Habib M. (2005). "Strategic environmental assessment can help solve environmental impact assessment failures in developing countries". Environmental Impact Assessment Review, 25(4), 307-317. doi: http://dx.doi.org/10.1016/j.eiar.2004.09.003.

Anjaneyulu Y. \& Manickam V. (2011). Environmental Impact Assessment Methodologies. Second Edition. CRC Press Reference-428 pages. ISBN 9780415665568 - CAT\# K12979. India

Annandale, David \& Taplin, Ross (2003). "Is environmental impact assessment regulation a 'burden' to private firms ?’. Environmental Impact Assessment Review, 23(3), 383-397. doi: http://dx.doi.org/10.1016/S0195-9255(03)00002-7.

Anonim. (2009). Undang-undang Rebulik Indonesia Nomor 32 tahun 2009 tentang Perlindungan dan Pengelolaan Lingkungan Hidup. Lembaran Negara Republik Indonesia Tahun 2009 Nomor 140. Jakarta. http://www.menlh.go.id

Anonim.(2012a). Peraturan Pemerintah Republik Indonesia Nomor 27 tahun 2012 tentang Izin Lingkungan. Lembaran Negara Republik Indonesia Tahun 2012 Nomor 48. Jakarta. http://www.menlh.go.id

Anonim. (2012b). Peraturan Menteri Negara Lingkungan Hidup Republik Indonesia Nomor 5 tahun 2012 tentang Jenis Rencana Usaha atau Kegiatan yang Wajib Memiliki Analisis Mengenai Dampak Lingkungan Hidup. Berita Negara Republik Indonesia Tahun 2012 Nomor 408. Jakarta. http://www.menlh.go.id

Anonim. (2012c). Peraturan Menteri Negara Lingkungan Hidup Republik Indonesia Nomor 16 tahun 2012 tentang Pedoman Penyusunan Dokumen Lingkungan. Berita Negara Republik Indonesia Tahun 2012 Nomor 990. Jakarta. http://www.menlh.go.id

Anonim. (2012d). Peraturan Menteri Negara Lingkungan Hidup Republik Indonesia Nomor 17 tahun 2012 tentang Pedoman Keterlibatan Masyarakat dalam Proses Analisis Dampak Lingkungan Hidup dan Izin Lingkungan. Berita Negara Republik Indonesia Tahun 2012 Nomor 991. Jakarta. http://www.menlh.go.id

Armitage, D. R. (2005). "Collaborative environmental assessment in the Northwest Territories, Canada". Environmental Impact Assessment Review, 25(3), 239-258. doi: http://dx.doi.org/10.1016/j.eiar.2004.06.012.

Braniš, M. \& Christopoulos, S. (2005). Mandated monitoring of post-project impacts in the Czech EIA. Environmental Impact Assessment Review, 25(3), 227-238.

Fandeli, C. (2000). Analisis Mengenai Dampak Lingkungan Prinsip Dasar dan Pemapanannya dalam Pembangunan. Penerbit Liberty. Yogyakarta

Hartley, N. \& Wood, C. (2005). "Public participation in environmental impact assessment implementing the Aarhus Convention". Environmental Impact Assessment Review, 25(4), 319-340. doi: http://dx.doi.org/10.1016/j.eiar.2004.12.002. 
Haydar, F. \& Pediaditi, K. (2010). Evaluation of the environmental impact assessment system in Syria. Environmental Impact Assessment Review, 30(6), 363-370. doi: http://dx.doi.org/10.1016/j.eiar.2009.11.003.

Heinma, K. \& Põder, T.. (2010). "Effectiveness of Environmental Impact Assessment system in Estonia". Environmental Impact Assessment Review, 30(4), 272-277. doi: http://dx.doi.org/10.1016/j.eiar.2009.10.001.

Hourdequin, M., Landres, P., H., Mark J. \& Craig, D. R. (2012). "Ethical implications of democratic theory for U.S. public participation in environmental impact assessment". Environmental Impact Assessment Review, 35(0), 37-44. doi: http://dx.doi.org/10.1016/j.eiar.2012.02.001.

Jarvis, A. P. \& Younger, P. L. (2000). "Broadening the scope of mine water environmental impact assessment: a UK perspective”. Environmental Impact Assessment Review, 20(1), 85-96. doi: http://dx.doi.org/10.1016/S0195-9255(99)00032-3.

Jay, S., Jones, C., Slinn, P, \& Wood, C. (2007). "Environmental impact assessment: Retrospect and prospect". Environmental Impact Assessment Review, 27(4), 287-300. doi: http://dx.doi.org/10.1016/j.eiar.2006.12.001.

Mariott, B.B. (!997). Practical Guide to Environmental Impact Assessment. The McGraw-Hill Companies. New York.

Momtaz, S. (2002). "Environmental impact assessment in Bangladesh : A critical review". Environmental Impact Assessment Review, 22(2), 163-179. doi: http://dx.doi.org/10.1016/S0195-9255(01)00106-8.

Morrison S, A., \& Bailey, M. (2009). "Appraising the role of relationships between regulators and consultants for effective EIA". Environmental Impact Assessment Review, 29(5), 284-294. doi: http://dx.doi.org/10.1016/j.eiar.2009.01.006.

Mursid, M., Razif, M. \& Boedisantoso, R. (2015a). Dokumen Evaluasi Lingkungan Hidup Pengoperasian dan Pemeliharaan Jalan Tol Surabaya-Gresik Provinsi jawa Timur. PT. Margabumi Matraraya. Surabaya.

Mursid, M., Razif, M. \& Boedisantoso, R. (2015b). Dokumen Amdal Jalan Tol KrianLegundi-Bunder sepanjang 29,2 km di Propinsi Jawa Timur. PT. Waskita Bumi Wira. Surabaya.

Nadeem, O. \& Hameed, R. (2008). "Evaluation of environmental impact assessment system in Pakistan". Environmental Impact Assessment Review, 28(8), 562-571. doi: http://dx.doi.org/10.1016/j.eiar.2008.02.003.

O'Faircheallaigh, C. (2009). "Public participation and environmental impact assessment: Purposes, implications, and lessons for public policy making”. Environmental Impact Assessment Review, 30(1), 19-27. doi: http://dx.doi.org/10.1016/j.eiar.2009.05.001.

Opoku, A.S. (2001). "Environmental impact assessment in developing countries: the case of Ghana". Environmental Impact Assessment Review, 21(1), 59-71. doi: http://dx.doi.org/10.1016/S0195-9255(00)00063-9.

Panigrahi, J. K., \& Amirapu, S. (2012). "An assessment of EIA system in India". Environmental Impact Assessment Review, 35(0), 23-36. doi: http://dx.doi.org/10.1016/j.eiar.2012.01.005.

Pischke, F. \& Cashmore, M.. (2006). "Decision-oriented environmental assessment: An empirical study of its theory and methods". Environmental Impact Assessment Review, 26(7), 643-662. doi: http://dx.doi.org/10.1016/j.eiar.2006.06.004.

Razif, M. \& Santoso, I.B. (2016). "Prediction of CO, CO2, CH4, and N2O Vehicle Emissions from Environmental Impact Assessment (EIA) at Toll Road of Krian-Legundi-Bunder in East Java of Indonesia". International Journal of ChemTech Research Vol. 9, No.03 pp 653-664. ISSN: 0974-4290. www.sphinxsai.com. 
Razif, M. \& Persada, S.F. (2016). "The calculation of Average Vehicles Emission from Environmental Audit in Toll-Road Surabaya-Gresik at Indonesia". International Journal of ChemTech Research Vol. 9, No. 6, pp. 653-664. ISSN: 0974-4290. www.sphinxsai.com.

Runhaar, H.V.L.; Frank, D., P. \& Arts, J. (2012). "Environmental assessment in The Netherlands: Effectively governing environmental protection? A discourse analysis". Environmental Impact Assessment Review, 39(0), 13-25. doi: http://dx.doi.org/10.1016/j.eiar.2012.05.003.

Saarikoski, H. (2000). "Environmental impact assessment (EIA) as collaborative learning process". Environmental Impact Assessment Review, 20(6), 681-700. doi: http://dx.doi.org/10.1016/S0195-9255(00)00059-7.

Sandham, L. A., \& Pretorius, H. M. (2007). "A review of EIA report quality in the North West province of South Africa". Environmental Impact Assessment Review, 28(4-5), 229-240. doi: http://dx.doi.org/10.1016/j.eiar.2007.07.002.

Sandham, L. A.; van Heerden, A. J.; Jones, C. E.; Retief, F. P. \& Morrison S. A. N. (2011). "Does enhanced regulation improve EIA report quality? Lessons from South Africa". Environmental Impact Assessment Review, 38(0), 155-162. doi: http://dx.doi.org/10.1016/j.eiar.2012.08.001.

Soemitro, R.A.A \& Suprayitno, H. (2018). “Optimasi Kasus Pengaturan Kombinasi Pemuatan n Paket Barang ke m Kotak Angkut”. Jurnal Manajemen Aset Infrastruktur \& Fasilitas. Vol.2, No.1: 11-21. Maret 2018. Surabaya.

Suprayitno, H. \& Soemitro R.A.A. (2018). "Preliminary Reflexion on Infrastructure Asset Management". Jurnal Manajemen Aset Infrastruktur \& Fasilitas, Vol.1, No.1, Maret 2018, Hal. 1-10.

Toro, J.; Requena, I. \& Zamorano, M. (2009). "Environmental impact assessment in Colombia: Critical analysis and proposals for improvement". Environmental Impact Assessment Review, 30(4), 247-261. doi: http://dx.doi.org/10.1016/j.eiar.2009.09.001

Turnbull, J. (2002). "Environmental impact assessment in the Fijian state sector". Environmental Impact Assessment Review, 23(1), 73-89. doi: http://dx.doi.org/10.1016/S0195-9255(02)00036-7

Yakin, A. (1997). Ekonomi Sumber Daya dan Lingkungan, Teori dan Kebijakan Pembangunan Berkelanjutan. Akademika Presindo. Jakarta. 
(e)ISSN 2615-1847 (p)ISSN 2615-1839

Jurnal Manajemen Aset Infrastruktur \& Fasilitas - Vol. 3, No. 1, Maret 2019 